Proceedings

\title{
Young Readers as Detectives: A Research Proposal for Democratic Reading Practices ${ }^{\dagger}$
}

\author{
Beatrice Anelli \\ Università Degli Studi di Padova, 35122 Padova, Italy; beatriceanelli@ymail.com \\ + Presented at the International and Interdisciplinary Conference IMMAGINI? Image and Imagination \\ between Representation, Communication, Education and Psychology, Brixen, Italy, 27-28 November 2017.
}

Published: 24 November 2017

\begin{abstract}
This paper wants to answer two questions: which types of detectives are children in silent books (s.b.)? Which type of investigations do they carry on? Starting from some possible answers, we will talk about one of the main characteristics of the s.b.: the richness of details. A detective is particularly accurate and curious, believing in the importance of even the smallest fragment, hoping to find the missing one that will lead him/her to solve the case. In the same way, the reader of s.b. becomes an investigator: missing of the guideline usually provided by written text, he/she needs to trust the narrative power of images and investigate them in detail, so to come to his/her personal discovery of the story. Any detail, however small and seemingly insignificant, can lead to multiple interpretations and give voice to everyone's opinion, constituting a democratic community of readers. On these basis, one could build a participated action research in primary school.
\end{abstract}

Keywords: wordless books; reading education; cooperative design

\section{Introduction}

The main aim to this paper is to focus the investigative-like activities of a young-reader of silent books (from now on s.b.). I will start with explaining the common ground between a reader and a detective. Then, the role of young-readers observing carefully the page in search for links, references, and novelties will be defined. Silent books have the characteristic to be image-based and to lack of any text, so they are the ideal tool for the job. Their peculiarities, starting from the iconic apparatus, enable careful and meticulous investigations which encourage the reader to not settle for a single reading, a single version of the story. In s.b., in fact, details are many and not equally visible, so much that they can escape a first, superficial reading.

Moreover, the lack of words guides also the weaker readers, or whomever has difficulties in expressing their ideas, to propose their own solution. Silent books appear as a democratic inclusive tool to be offered to children from pre-primary school (without any literacy skill) as to the elder ones. Given these characteristics I believe it is possible to build a different modality to read s.b. with young readers, even the ones already autonomous in reading written texts.

Considering what will be said in Sections $2-4$, in the last one (n. 5) I will identify a new proposal for an action research to enact in primary school (middle years)

\section{Theoretical References}

\subsection{The Reader-Detective}

When approaching a s.b., children act similarly to investigators: they observe carefully and with curiosity, look for details, make inferences, trace back their steps, change their minds. And just like a detective, they propose solutions, reflect on them, and negotiate them. 
The absence of words makes the readers even freer to interpret the iconic text, disclosing infinite possible interpretations. There are iconic books where interpretations can be clearer and less subjective, even though never univocal, and others in which they are infinite and all yet correct and plausible. Detective's one is not a simple job, then, when solutions can be so different and it is necessary, willingly or not, to rely on an investigative technique in order to "follow the string" (quoting a famous s.b. by William Wondriska-A long piece of string) and find the "culprit".

A possible method could be the one defined by Forster and Mazzucco ([1], p. IX), in reference to Aby Warburg: the philology of the detail, "un metodo che richiede lentezza, approfondimento, attenzione e rispetto nei dettagli" (a method which calls for a slow pace, deep thought, attention and respect in the details). Here, details are seen as fragments of a yet unknown whole. Just like the famous Pezzettino, main character of its namesake by Leo Lionni, who is always trying to figure himself out and finds himself complete only with each and every one of his fragments. The fact that Pezzettino has found himself (once more) does not guarantee that he will not question himself ever again. Just like the reader, once discovered his/her own interpretation key for a s.b., might want to look back at it to confirm it or deny it in face of a new investigation. In fact, every s.b. has one or more directions of reading, starting with the book artefact itself, for example. At the same time, it contains multiple internal references on different levels of meaning and, sometimes, even a circular structure (e.g., the typical one of Weisner's books) which makes the reader go back on his/her steps ([2], p. 63).

Continuing in the parallel with the detective, a (young) reader of s.b. is careful in what might appear insignificant at first sight, as for example a flyleaf. The pages we usually skip to get straight to the beginning of the text, actually can mean the most in s.b., being reference and connection. In fact, they can recall the main structure of the book, uncovering useful particulars for comprehension, they can disclose that cyclical motion which makes the reading practice complete. The reader-detective, then, is called to be vigilant from the very beginning, accurate also in observing iconic structure and exercise his/her sight from the hard cover and flyleaves, before entering the main plot.

An investigator on a case has some past experiences that can help with modalities, problems, examples of situations useful for the present case to solve. This personal knowledge is for the reader the history of his/her readings, which will help him/her to orient better also in unfamiliar contexts.

It is enough to think to "Nella nebbia di Milano" by Bruno Munari (Figures 1 and 2), edited by Emme in 1968 and then again by Corraini. In perfect Munari style, its overlapping pages of different transparencies create the fog effect on the bare ground, and at the same time a sense of wait and suspension typical of a metropolis. The young reader find him-/herself walking among the pages of a maybe unfamiliar city-like reality, but nonetheless he/she can glimpse at known elements that peep out of the pages of a book which recalls his/her own iconic memories, making the reader remember that within the silence, also images have a voice.

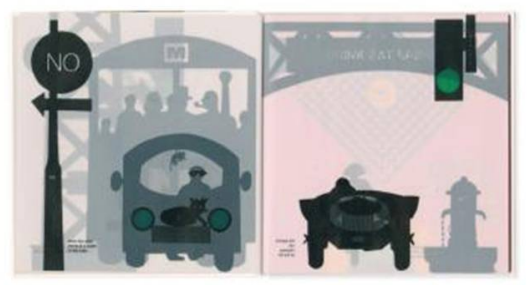

Figure 1. Munari B., Nella nebbia di Milano, ed. italiana e inglese; Corraini, Italia 2008, [1].

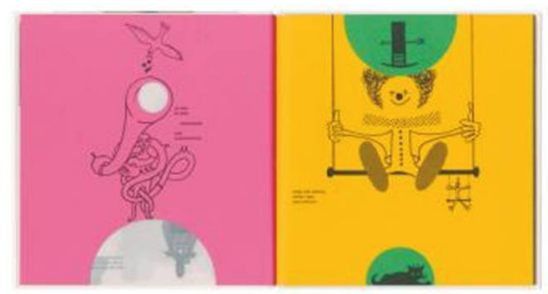

Figure 2. Munari B., Nella nebbia di Milano, ed. italiana e inglese; Corraini, Italia 2008, [2]. 
The detective's personal perspective here described resembles the one of a Paul Auster's character ([3], pp. 10-11):

"l'investigatore è una persona che guarda, che ascolta e che si muove attraverso la palude degli oggetti e degli avvenimenti a caccia del pensiero, dell'idea che farà concordare ogni dettaglio e gli darà un senso [...]. Si è ridestato alle cose che lo circondano quasi che gli potessero parlare; quasi che in virtù dell' attenzione che ora riserva loro, assumessero un significato altro dal mero dato della loro esistenza. Private eye. Occhio provato. Per Quinn il termine racchiudeva un triplice significato. Eye non suonava semplicemente come "ai", la " $\mathrm{i}$ " iniziale di investigatore; era la " $\mathrm{I}$ " maiuscola, il pronome "io", e l' Io, il minuscolo germoglio sepolto nel corpo dell' essere vivente".

In this perspective, the reader lives on the research, he/she does not passively look on things but engages with them: he/she is at the same time reader and writer of the story. He/she sees what everybody can see on the stage, and also what is private and becomes clear only after a peculiar type of observation.

The information collected by the young reader-detective need to be recomposed, edited to achieve the final goal.

Another characteristic of the reader-detective is the management of silence. In s.b. there is a duplex type of silence: the one provided by the lack of words, and the one typical of the necessary concentration for the research of the detail. As an investigator craves for quiet and silence to think, to gather all the pieces and find a meaning to the events, in a similar way the reader looks for a condition of visual serenity to catch the details and connect them in the frame of the double page of a book. It is not an invisible silence, then, but one that wants to be found, to be part of a whole. A silence which awaits to be broken and discovered by the reader's words, be they thought or said. It is a temporary silence, which is already denied in the mind of the author, carrying on a certain story. It is an apparent silence, ready to be declared to the world.

In order to be a good reader-detective, one needs to be accurate, vigilant, able to make connections and find accords and discords, to be open to listen to the silence and not discard those details that appear insignificant at a first glimpse.

\subsection{Minimal Details, Maximal Interpretations}

“[...] anche come documento, l'opera d'arte rimane indeterminata, nel senso che non può mai essere definitivamente, inequivocabilmente definita. Ogni ricercatore deve dunque essere in grado di reagire in modo differente alle opere $\mathrm{d}^{\prime}$ arte a seconda delle circostanze" ([1], p. 24).

According to Terrusi ([2], p. 41), Warburg himself is the best example of open interpretation, being words entrusted to images, in his books. In fact, s.b. as Mnemosyne (by Warburg), can be defined as figurative atlases, collections of hints and forms that lead different readers to different stories, and are bound partly to the reader's skill to link and compare. What enable this differentiated reading are more and less visible details which require careful reading and aware sight.

These fragments can be visible to find in minimalistic pages or in much richer ones. In the latter case, we face the so called wimmelbücher: books swarming with details as the ones by the German Ali Mitgutsch's Mein Wimmel Bilderbuch (Figure 3), for example, edited by Ravensburger. Here, a beautiful garden gives the stage for children's daily activities, creating a photograph of the moment. Moreover, Rotraut Susanne Berner's books, among which the one referred to the seasons, so rich with details to search for and with stories to tell: Le Livre des 4 Saison, edited by Joie de Lire (Figure 4). Picture books, and stories in general, about daily life are always interesting. On this topic there is a fervent discussion among the researchers. For example, Roland Barthes ([4], p. 115) asked "perchè, in opere storiche, romanzesche, biografiche, c'è (per alcuni fra cui io) un piacere a veder rappresentare la "vita quotidiana" di un'epoca, di un personaggio? Perché questa curiosità dei minuti particolari: orari, abitudini, pasti, alloggi, abiti, ecc? È forse il gusto fantasmatico della realtà?".

An other example of s.b. linked to daily life activities is "Sunshine" by Jan Ormerod (Figures 5 and 6), where we can see a little girl's activities through the day, in deep physical and narrative silence. Her movements appear slow, studied, recurring, learnt through practice, and enable the reader 
to identify almost immediately with the little character. Both looking for a future, complete autonomy, they enjoy what they are already capable of doing at the moment. Another example is "The carpenter" by Bruna Barros, edited in Italy by Il Leone Verde, in which a dad enters his son's world to play with him and share daily experiences. Somewhere between real and dreamlike worlds, this book allows immediate identification with the characters and both a child's and an adult's keys of interpretation of the world.

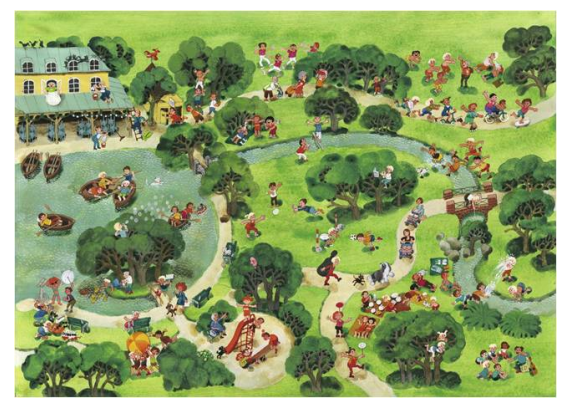

Figure 3. Mitgutsch A., Mein Wimmel Bilderbuch; Ravensburger, Germania 2010, [3].

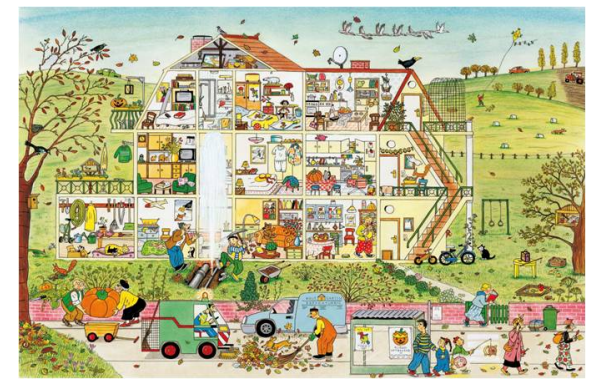

Figure 4. Rotraut Berner S., Le Livre des 4 saisons; La Joie de Lire, Francia 2013, [4].

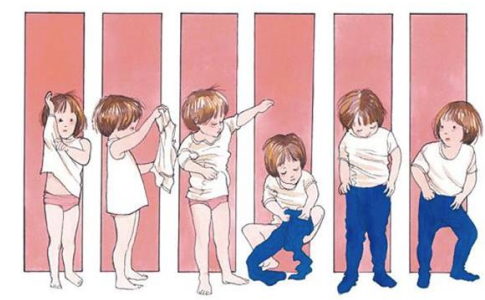

Figure 5. Ormerod J., Sunshine; Frances Lincoln, Inghilterra 2005, [5].

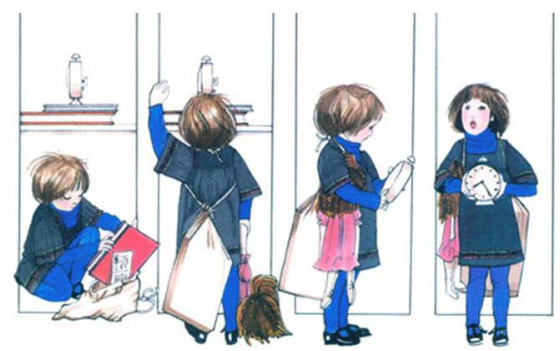

Figure 6. Ormerod J., Sunshine; Frances Lincoln, Inghilterra 2005, [6].

The research for details, on a micro and macro level, is like a scavenger hunt in which the reader tries to give sense to what it is before him/her, getting inspired by what is visible, what he/she has read before, what he/she knows about the world. In this way, every reader is responsible of the order given to the elements, bound to his/her own choice of investigative perspective in observing the details, making links and noting discontinuities. Every reader looks for details personally relevant to 
the construction of the story. That is the very beginning to make ever new discoveries whenever a page is turn, and a book re-read. A continuous attention to the fragment, to arrive to one's personal interpretation, is the core of this peculiar narrative experience.

The elements found can be minimal in size and in their apparent importance. In the second half of 1800 Giovani Morelli, referring to the erroneously neglected details in art pieces, uses the term "paradigma indiziario". With this term he identifies the small, usually overlooked, details which could indeed lead to recognize the artist with more or less ease: beyond public things, visible to everybody, it is necessary to examine the neglected details ([5], 1986).

These details are an important part of the investigative method that starts from hints to achieve one and only one possible final solution. In s.b., hints, once noticed, cannot be considered in isolation, but as part of a whole to build, a ramification of yet the same tree that creates with other hints, and the whole itself, the known "Indovina che cosa succede. Una passeggiata invisibile", by the famous author Gerda Muller (Figures 7 and 8). Here there are footsteps to follow, mysterious characters, hints dropped along the path and some little help to guide the reader. We find yet another recall to daily life in the presence of a child's bedroom with an unmade bed. Small footprints cross the room, going to the bathroom to get dressed, have breakfast and exit the house. In their walk, these steps will meet other footprints and, eventually, go back home.

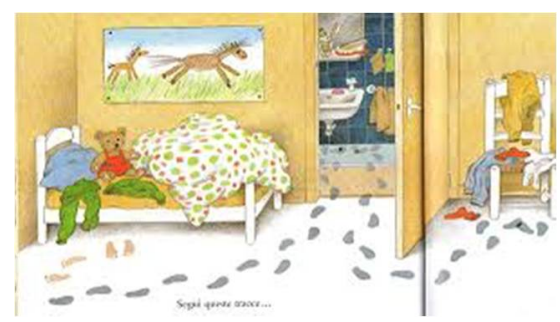

Figure 7. Muller G., Indovina che cosa succede. Una passeggiata invisibile; Babalibri, Italia 2001, [7].

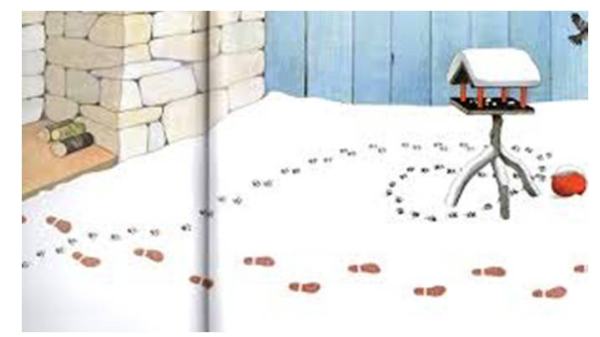

Figure 8. Muller G., Indovina che cosa succede. Una passeggiata invisibile; Babalibri, Italia 2001, [8].

\subsection{A Democratic Reading}

Wanting to include the s.b. within the typology of the illustrated allies, without going into the debated issue of representing a literary genre or a set of genres, we can find among them a difference in the relationship between the act of reading and the role of the reader. "Un albo illustrato per raggiungere il suo compimento richiede una relazione, almeno alla prima lettura, tra lettore ad alta voce e ascoltatore" ([6], p. 134). With small readers not yet literate, meeting with a reader who is able to read is the keystone that sets the beginning of the relationship between the reader and the book. From that moment onward, the small reader can be autonomous, as he/she has all the elements to continue on his/her own, knowing the story in its parts (including the texts), and he/she is free to play with the book as he/she wishes. In the s.b., instead, the absence of written word eliminates the need of a literate reader to approach at the text: the reading of images can be made autonomously also by a very small, non-literate, foreign reader. Here is the first democratic feature of reading s.b.: all readers are capable readers of a s.b. Reader types are infinite, of all languages, close and far, educated or not: in s.b. they feel welcomed and all at the same level. Shaun Tan [7] declares this multiple destination of s.b. believing all the interpretations as alive, right and changeable. He also adds that the two categories of 
most fascinating readers are children and people of other cultures, because they emphasize the democracy of wordless texts. There are therefore no age-related or prior knowledge-related disparities, although a young trained reader can perform a deeper visual reading, but a parity of roles: in front of s.b. we are all equal, we are all interpreters.

In this relationship between the young reader and the s.b., does then the adult literate disappear? Surely not, he is the mediator who must spread the knowledge of these books too often wrongly considered just for young children. These can approach an uncertain and hesitant audience, bringing the wonder of the images to a skeptical audience, young or mature. The role of expert reader mediator is also present in this relationship, even though it is outlined differently. He does not have the leading role as a reader of a written text, but may call for careful observation, a necessary concentration, a lively curiosity, to establish links that, when discovered, alone or together, are surprising. Thus, it is recognized the pedagogical need to defend and facilitate everyone's access to the book ([2], p. 19). This inclusion policy is another democratic aspect of the s.b., where also thanks to the presence of mediators each one can activate their own personal search of clues.

The reading of s.b. is therefore an inclusive reading format that includes also those who are not literate or who are at a lower level than their classmates (e.g., acting within a class group) and which allows everyone to express their own idea, opinion, and story. The project proposed in the next paragraph starts from these goals: the reading of s.b. as a tool for bringing children closer to reading, and as an inclusion tool. The described proposal is deliberately generic as it is flexible according to the established research context, and can face many possible changes. Here is a general idea to follow as a basis, plus some methodological ideas and bibliographical references to look at. The first theoretical basis from which to start is the one presented in the preceding paragraphs: the meaning of a young reader-the investigator, the importance of attention to detail and the reading of silent book as a democratic moment.

\section{Proposal for an Action-Research: “Silence for the Readers!"}

The first use that comes to mind thinking of s.b. is the rupture of their silent structure to enter the written words. But the experiences of meeting with s.b. they do not run out of rewrite, drama, drawings, etc. ([2], p. 42), verbalization is not the only answer ([8], 2013).

How can we then propose these silent readings to young readers?

You can propose the s.b. as an occasion for a "classical" conversation, returning to the democratization described above, where all the readers talk equitably about how much they have seen. Or you can plan group readings with stimulus questions and shared discussion. Instead, the present proposal takes into consideration the possibility of creating thematic schedules from reading s.b.

Illustrated books that appear in the form of catalogs, atlases, and inventories have grown considerably in recent years and are becoming a format for the child's editorial landscape. They talk about nature, animals, art, travel, dreams, and more, and represent one of the ways to tell a story, and in some cases to make divulgation to the children. The idea is to start reading s.b. with the aim of sorting a kind of shared catalog of the clues found in illustrated books, inspired by the existing book-inventory structure.

The objective of the proposal called "Silence reads" is twofold: on one hand, bringing children closer to reading and learning about a type of texts that many of them may never know; and on the other hand to create in the classroom a reading moment with a democratic climate where all the readers are on the same level regardless of their reading-writing skills. The reference target is primary school, typically third and fourth grade, so that in the group there are possibilities for intercepting both the so-called strong readers, and children who for various reasons have no confidence in the book; both children who already read independently with no problems, and children who see in reading still the effort and fatigue. The subjects involved are the expert, the classroom teachers, the class, the local authorities (libraries). The methodology conceived and justified in the next lines is the research-action with particular attention to cooperative collaboration among teachers and a long span of time that can accompany the students in at least 3 years (also for this reason the need to start from a third elementary). A genuine cooperation "richiede, oltre alla condivisione delle finalità, anche lo 
stabilire, di comune accordo, la procedura sperimentale da seguire" ([9], p. 86). Thus, the entire circular process of action research, according to the well-known Cunningham model represented in 1976 [10], is thought, shared, negotiated and renegotiated by common agreement between the expert and the group of reference teachers (together they will form the group of work). The reference methodological framework is therefore that of participatory action research in which the actors involved are aware and active, and to have a more analytical stage, the reference goes to the eleven phases written by Coggi and Ricchiardi ([11], p. 69). Knowing that you cannot go to the search for a problem, that you should not create it, that you do not have to stereotype other projects ([12] p. 43), action research can be started from an area survey related to the attention that exists in school environments for reading education. This has to focus on two details: the presence of a reading time in the classroom, and the presence and use of illustrated books in the classroom, school and/or communal library. The observation grid used can then have a funnel structure and, after the analytical chart of the site under discussion, answer the following questions: is there an institute library? Are there class libraries? If so, what kind of books are there? Are there, among them, also illustrated books and in specifics s.b.? With what mode, if any, are they used? Are there any reading education activities? Which are they? Who are the subjects involved? Do these activities include the use of illustrated books and s.b.?

In this exploration phase, it is also important starting to get in touch with those who are as potential school referents for any proposed project. In fact, it is very important for the researcher to have in the school the reference figures to ask to be part of the working group, voluntarily adhering to, and to rely for possible bureaucratic issues known only to the ones who have long worked inside the context.

After this first exploratory phase, the expert, based on the data collected in the observation grids and now having a general idea of how the subject is dealt within the territory in which he/she operates, extracts what may be the most suitable interlocutor to propose a reading education design for the primary school focused on the s.b. Starting with a basic idea (e.g., this school has a mediocre school library and there are no reading related activities), he/she proposes an action (e.g., how can I put a reading project on the s.b. in such a context, so to induce reading and to make known the genre?). Once decided the school, he/she can go deeper into the investigation by describing the situation better: "è necessario descrivere nel modo più completo possibile la natura della situazione che si vuole cambiare e migliorare" ([13] p. 7). To do this, it may be useful to find the right contacts in the school and then deepen knowledge of the situation directly with potential stakeholders. Once the new data is collected, one can think of a first proposal, structured accordingly on the characteristics of the site identified, to present to the school. Starting from a general idea of activities to be done in classrooms with s.b., the proposal is modeled on the basis of the chosen context.

The general idea here is as follows: to create a moment in the classroom devoted to reading together, starting from the illustrate books and in particular the s.b. Depending on the knowledge that the teachers involved have in the subject matter, decide whether or not to imply an initial training course. After reading together with the children a good number of s.b., one could proceed with the drawing up of an inventory of some recurring elements, drawing up the inventory from notes of illustrated books that already have this structure. This idea, though very general, can be written already by following the basic ladder that will be used throughout the project, both to redraw the initial one and any likely change it in its progress The so-called project grid can be formed by: objectives, recipients, subjects involved, duration, progress (phases and purposes of each phase), necessary resources (places, materials, tools), costs. The way of presenting the general idea can be of a different nature: email, paper to a teacher, paperwork directly to the schoolmaster, during a special meeting. A person's interview allows you to immediately verify the presence of any involvement and awareness of a deficiency on the subject in question. Following this direct contact, a mail allows you to recall some points that emerged in the interview, clarify them, and make further changes to the document. This first stage of meeting is very important because it begins to create a relationship of trust that will be crucial to the success of the project, whatever its outcome. Once the school has shown 
interest in the proposed project, it may be necessary to ask the teaching team for a voluntary membership.

Depending on the choice of teachers, the working group will be formed and it will accompany the progress and monitoring of the project for the reference school year. Together with the working group you will redefine the general idea of defining what class(es) or group(s) of children are involved and responding even more accurately to the detected shortcomings. For example, as previously suggested in the absence of specific knowledge, a training course (also structured in cooperation with the group) can be conceived, open to those who do not adhere to the "practical" project, which briefly illustrates the history of the record illustrated and s.b., which shows examples and features of format and content, which proposes group and singular reading mode. Another example, in case of absence or lack of books and in particular of illustrated books, you can make a selection to be offered to the school with the delivery of general and reasoned bibliographies, and upon arrival of the recommended books arrange for a moment of vision and reading shared by involving teachers and pupils together.

The rewritten project is now ready to take shape and can be monitored using two typical tools of action research and qualitative research, such as focus groups and journals. The first can be both a further exploratory phase (initially) and a follow-up to the project's progress (during the school year), and in the final stage it can help to discuss the outcome and to begin thinking about how to continue the next year. They also represent starting points to identify the categories to work on, for project negotiation. Even the changes, which are likely to happen in the work, are collaboratively revised together by finding an agreement of intent, mode, and content. This from the very beginning that the maximum concentration goes to the process and not to the final product. On-board diaries, on the other hand, tell and document what is happening throughout the project by all members of the workgroup and can be a useful tool for field researchers to receive even more personalized feedback. In addition, a regularly-held diary allows you to note sensations related to proven emotions, particular attitudes, and reactions. And keeping it child-friendly also makes it possible to make a comparison between what the adult feels in a given situation and what the child feels in the same one. This comparison can be very useful to the researcher and the teacher to get any changes in the work method and attitude. Educating is not a private affair ([12], p. 47), but it involves all the subjects with whom we talk, especially if they are the recipients of our actions. Some suggestions to be inspired to structure the project and the activities:

- the proposed classroom proposal about the time of reading must be gradual and if possible take regularity from the beginning. At that time, the teacher must participate in the activity just like his pupils. To have some indication of how to handle it, refer to the volume of Aidan Chambers [2];

- $\quad$ the choice among s.b. is really vast in recent decades. Depending on the type of inventory you plan to make (even this choice can be taken in classroom with students) you can opt for a variety of different books for content and structure. For example, it is possible to make a catalog of animals in s.b., houses, actions, colors, illustration techniques, etc. Once the object of the catalog has been established, the s.b. bibliography will be enriched realizing a specific topic;

- the choice of structured inventories from which to draw is also quite large. You can get started from wimmelbücher including, for example, the classics of Richard Scarry, and recreate a catalog with image and legend deciding whether or not to add more explanations. The series called Inventari Illustrati of the publishing house Ippocampo presents themed subjects (animals, plants, flowers, birds, insects, mountains, sea, wonders of the world) and can be used both as a graphical and content comparison (Figures 9 and 10 ). The book "Welcome to My House" by Gaia Stella, edited by Chronicle Books (Figure 11), the BlexBolex's books: "Ballata"; "Seasons"; "Imaginary" (Figures 12 and 13) edited in Italy by Orecchio Acerbo, or even Steven Guernaccia's books published by Corraini: "Cinderella"; "Three Little Pigs"; "Goldilocks and the three bears" (Figure 14); 
- in explaining to the children the work of the detective, and hence theirs, you can also read brief police stories that bring the skills that you want to put in the field: attention, watchful eye, curiosity, attention to details.
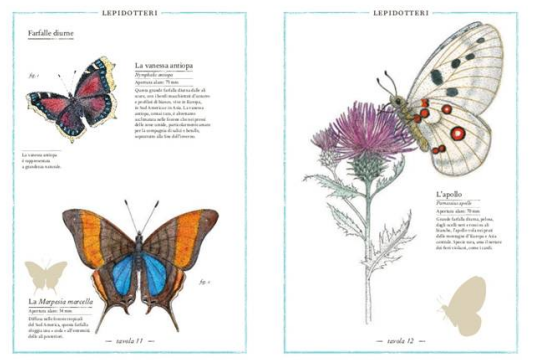

Figure 9. Tchoukriel J.; Aladjidi V., Inventario illustrato degli insetti; Ippocampo, Italia 2013, [9].

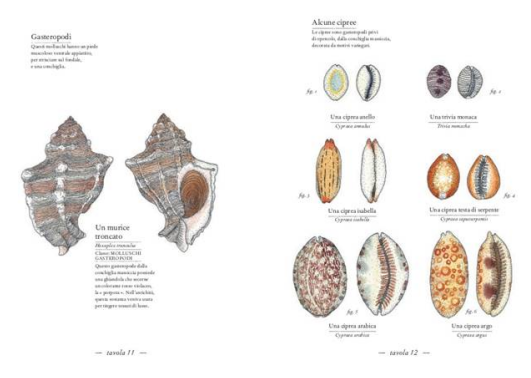

Figure 10. Tchoukriel J.; Aladjidi V., Inventario illustrato del mare; Ippocampo, Italia 2011, [10].

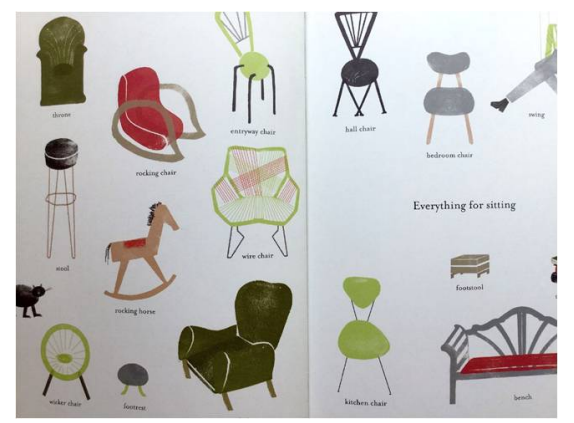

Figure 11. Stella G., Welcome to My House; Chronicle Books, California 2017, [11].

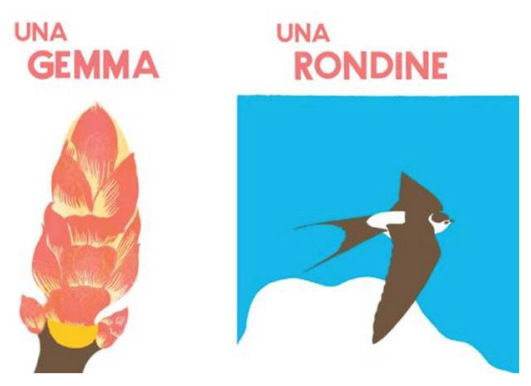

Figure 12. BlexBolex, Stagioni; Orecchio Acerbo, Italia 2010, [12].

In such structured research, the cooperative work of the working group is crucial. In fact, the design dimension is always active, being it, as in the definition of Lipari ([15], p. 13), a specific way of thinking, organizing and acting within a structured action field where goals, resources and constraints are visible. This allows the actors-designers to organize ideas, knowledge and information, to finalize and organize the action by controlling the course, evaluating the results achieved. There is 
therefore a continuous passage between action and reflection. All these actions take time for discussion in a slow comparison perspective that does not require an immediate result but a focus on the trend. If possible, it is advisable to exclude such activities from a numerical evaluation but to leave them as an extra evaluation activity or possibly as an activity from which to draw additional indications but not to see the students being voted on. This goes hand in hand with the democratic optics in which the project is proposed and sees all participants at the same level and all possible bearers of knowledge. Reading is therefore a democratic device where everyone is involved, which goes hand in hand with a type of field research where the moments of confrontation and reflection are fundamental.

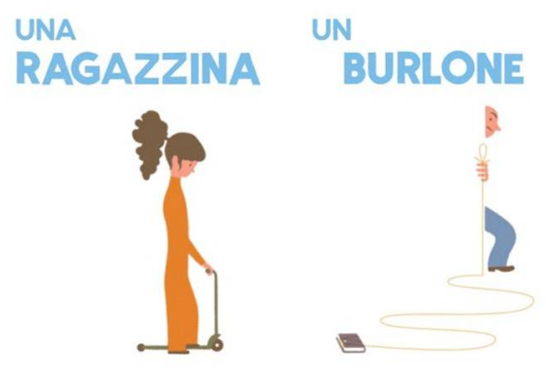

Figure 13. BlexBolex, Immaginario; Orecchio Acerbo, Italia 2008, [13].

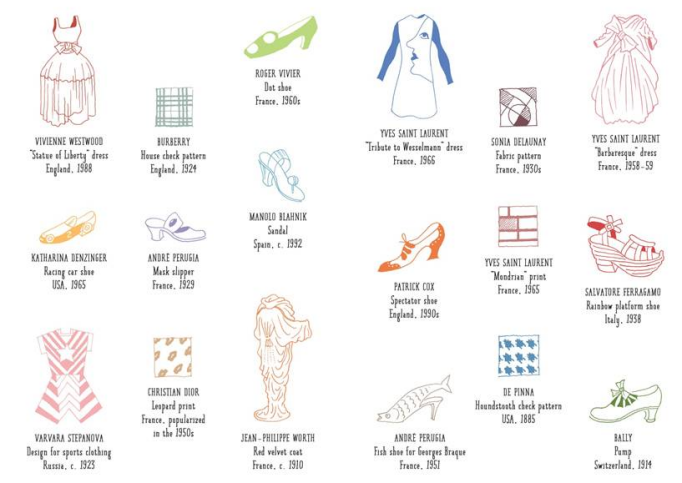

Figure 14. Guernaccia S., Cinderella a fashionable tale; Corraini, Italia 2013, [14].

Conflicts of Interest: The authors declare no conflict of interest.

\section{References}

1. Forster, K.W.; Mazzucco, K. Introduzione ad Aby Warburg e All'atlante Della Memoria; Bruno Mondadori: Milano, Italy, 2002.

2. Terrusi, M. Meraviglie Mute. Silent Book e Letteratura per L'infanzia; Carocci: Rome, Italy, 2017.

3. Auster, P. Trilogia di New York; Einaudi: Milano, Italy, 1996.

4. Barthes, R. Variazioni Sulla Scrittura Seguite da Il Piacere del Testo; Einaudi: Milano, Italy, 1999.

5. Ginzburg C. Miti, Emblemi e Spie; Einaudi: Milano, Italia 1986.

6. Terrusi, M. Albi Illustrati. Leggere, Guardare, Nominare il Mondo nei Libri per L'infanzia; Carocci: Rome, Italy, 2016.

7. Tan, S. Per Chi Sono Questi Libri? Andersen Volume 309; Anno: Genova, Italy, 2014.

8. Arizpe, E. Meaning-making from wordless (or nearly wordless) picturebooks: What educational research expects and what readers have to say. Camb. J. Educ. 2013, 43, 163-176.

9. Trombetta, C.; Rosiello, L. La Ricerca-Azione. Il Modello di Kurt Lewin e le sue Applicazioni; Erickson: Trento, Italy, 2002.

10. Cunningham, B. Action Research: Toward a Procedural Model; Human Relations Volume 29 (3); Sage Publishing: Thousand Oaks, CA, USA, 1976.

11. Coggi, C.; Ricchiardi, P. Progettare la Ricerca Empirica in Educazione; Carocci: Rome, Italy, 2005. 
12. Traverso, A. Metodologia Della Progettazione Educativa. Competenze, Strumenti e Contesti; Carocci: Rome, Italy, 2016.

13. Elliot, J.; Giordan, A.; Scurati, C. La Ricerca-Azione. Metodiche, Strumenti, Casi; Bollati Boringhieri: Torino, Italy, 1994.

14. Chambers, A. Tell Me: Children, Reading and Talk. The Reading Environment. How Adults Help Children Enjoy Books; Thimble Press: Stroud, England, 1995.

15. Lipari, D. Idee e Modelli di Progettazione; Lavoro: Rome, Italy, 1987.

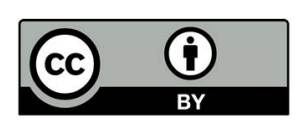

(C) 2018 by the authors. Licensee MDPI, Basel, Switzerland. This article is an open access article distributed under the terms and conditions of the Creative Commons Attribution (CC BY) license (http://creativecommons.org/licenses/by/4.0/). 